\title{
Якутское радио в годы Великой Отечественной войны: редакция политического вещания
}

Во Всесоюзном радиокомитете при председателе Г.И. Стукове еще в 1940 г. было организовано Управление местного вещания, которое направляло деятельность краевых, республиканских, областных радиокомитетов и трансляционных радиоузлов для оперативного руководства и организации практической помощи им. В организационном отделе Управления местного вещания было создано семь групп среди вещательных центров. Во вторую группу вошли 20 радиокомитетов, и в их числе был Якутский радиокомитет Всесоюзный радиокомитет начал монополию на радиопередачи местного вещания ещё в середине 1930-х гг., когда создавались региональные радиокомитеты. В те годы звукозаписывающего устройства не было. "Живой" эфир проводили дикторы, которые читали готовые материалы или выступающий читал у микрофона текст, проверенный редакторами политической редакции (ГА РФ. Ф. Р-5446. Оп. 24. Д. 496. Л. 9-14. О создании во Всесоюзном радиокомитете Управления местного вещания и Художественного совета) ${ }^{1}$.

На рубеже XX-XXI вв. появились исследования истории политического вещания военного периода на местном материале регионов, раскрывающие значимость радиопередач общественно-политического содержания [3; 4; $6 ; 10 ; 11]$. Изучение роли политического вещания продолжалось исследователями, которые выявили важные фракты усиления партийного руководства радиовещанием в организации политической информации при содействии Управления пропаганды и агитации ЦК ВКП (б), которое установило обязательное время передачи агитационно-пропагандистской информации - не менее шести часов в сутки. Далее историки отмечали, что образцом для вещания в местном радиокомитете явились передачи Всесоюзного радио, которые определяли главное направление и задачи: крепить единство фронта и тыла, воспитывать патриотизм, сплачивать народ, пропагандировать трудовой и боевой героизм $[7 ; 8 ; 12]$.

Якутское национальное радио выполняло с началом войны основную фрункцию оперативного оповещения населения Якутской АССР о положении на фрронтах. Поэтому в информационном формате вещательной сетки радиопрограмм главное место занимало политическое вещание, над которым работали редакторы, переводчики материалов ТАСС и Совинформбюро, радиокорреспонденты и дикторская группа на якутском и русском языках (НА PC (Я). Ф. 898. ОП. 5. Д. 1. Л. 41. Отчет Якутского радиокомитета за 1941 г. $)^{2}$. В первый день войны, вечером по якутскому времени, местное радио выдало в эфир по поручению Советского правительства экстренное заявление первого заместителя председателя Совнаркома СССР, Наркома иностранных дел CCCP B.M. Молотова "О вероломном нападении германских войск на нашу страну". На следующий день по местному радио передавали репортаж об участии трудовых коллективов Якутского радиоцентра, типографии, кожевенного завода, пожарной охраны г. Якутска в проведении митингов, а вечером дикторы повторно читали текст обращения Молотова "Наше дело правое. Враг будет разбит. Победа будет за нами!" с переводом на якутский язык. Поз-

1 ГА РФ - Государственный архив Российской Федерации.

2 НА РС (Я) - Национальный архив Республики Саха (Якутия).

(С) Петрова В. Д., 2020

ПЕТРОВА Валентина Дмитриевна, соискатель Института гуманитарных исследований и проблем малочисленных народов Севера СО РАН (2. Якутск). E-mail: petrova-vd@mail.ru 
же, 3 июля 1941 года по радио передавалось выступление председателя Государственного Комитета Обороны И. Сталина, время выступления которого заранее объявили трудовым коллективам и учебным заведениям города. Об этом свидетельствует приказ директора Якутского педагогического института: "чтобы сотрудники института прослушали правительственное сообщение по радио, перенести обеденный перерыв на сегодня с 12.30 до 13.00 часов" [9, c. 195].

Уже с объявлением о начале войны редакторский состав изменился. В июле 1941 года в республике был объявлен призыв граждан в ряды Рабоче-Крестьянской Красной Армии. Одними из первых были призваны председатель Якутского радиокомитета Г.П. Тихонов и его заместитель Х.Ф. Унаров, главный редактор Единого сектора художественного вещания В.С. Уваров. Также на первый призыв граждан 1921-1922 гг. рождения получил повестку диктор радио П.Т. Аргунов. Одновременно уволилась редактор отдела выпуска радиопрограмм В.К. Захарова по собственному желанию, и как выпускница Якутского аэроклуба подала заявление в Городской военкомат с просьбой отправить на фронт. В последующем получил повестку начальник сектора узлового вещания Д.Т. Прокопьев, который был снят с военного учета по состоянию здоровья, чуть позже ушёл на фрронт первый диктор Якутского радиокомитета 1934-1938 годов, младший сержант И.Д. Новгородов, также повестки получали уполномоченные радиокомитета в районных трансляционных радиоузлах.

Радиокомитет работал с 8 часов утра. С открытием станции транслировались новости из Москвы в 07.20 по 25 мин., 18.45 по 1 ч. 45 мин., 21.00 по 15 мин., 22.30 по 20 мин., сообщения Совинформбюро передавались в эфире в 08.15 ч., 17.50 ч., 21.30 ч., 23.30 ч., а также местные выпуски "Последних известий" четыре раза в день. По радио слушали выступления руководителей республики, лекторов-пропагандистов, передовиков производства сельского хозяйства и промышленности. Между политическим вещанием чередовали передачи музыкально-художественных программ, кроме того транслировали передачи из Хабаровска. Радио вещало до полуночи. Радиокомитет приказом отменил очередные отпуска работников, которые заменили денежной компенсацией за неиспользованный отпуск. Война поставила новые задачи на политическом вещании. Боевой настрой и трудовой подъём творческого коллектива стали главными принципами в организации помощи тыла фрронту против германского произвола на территории Советского Союза (НА PC (Я). Ф. 898. ОП. 4. Д. 23. Л. 48-86; Д. 26. Л. 1-59; Д. 27. Л. 1-50. Программы радиопередач на 1941, 1942 гг.).

Якутское радио передавало в эфир за первые месяцы свыше двухсот заметок идейно-политического содержания и статей о начале войны, создании фонда обороны, трудовом подъёме работников на призыв руководителей республики, стахановцев промышленных предприятий и передовых колхозников. Редакторы постоянно освещали производственный энтузиазм социалистического соревнования. Якутский областной комитет ВКП (б) занимался подбором и расстановкой кадров на вещании. Редакторами политической редакции работали члены партии М.М. Захаров, М.П. Харлампьев, И.И. Кымов, Е.П. Мигалкина, М.И. Цимахович, М.П. Ощепков, Ф.Д. Дьячковский, Г.П. Багынанов, К.Е. Захаров, И.К. Сухушин, Е.И. Филатова, В.С. Николаев. Переводчиками материалов ТАСС с русского на якутский были А. К. Тимофеев, С.С. Львов, М.Е. Неустроев. Новости читали у микрофона дикторы первой категории М.С. Белолюбский и Н.П. Черкашина, дикторы второй категории Л.Д. Дитятина и И.Н. Данилов, старший диктор Х.П. Аржаков, диктор В.Т. Абрамова. Радиотехниками работали Д.А. Рабинович, А.К. Некрасова и др.

При назначении работников на ответственные должности учитывались такие качества, как партийность, дисциплинированность и образованность. Бюро Якутского обкома партии отметило главное направление в работе Якутского радиокомитета - выполнение решений партийных и советских структур, оперативное освещение положения на фрронтах и реализация производственных планов. На одном из плановых совещаний секретарь обкома партии представил на место, ушедшего на фронт руководителя, нового председателя радиокомитета В.К. Алексеева, выпускника Якутского педагогического техникума по специальности "политпросвещение", который работал до этого кор- 
ректором в типографии, затем корреспондентом, редактором и заведующим отделом в печати (НА РС (Я). Ф. 898. Оп. 2. Д. 7. Л. 32. Личные дела). Василий Климентьевич руководил радиокомитетом до конца мая 1945 года, и позже в 1985 году вспоминал об этом: "В военные годы коллектив дружно сплотился и работал с желанием. Женщины, у которых мужья воевали на фрронте, также трудились усердно" [1, с. 53]. Председатель смело практиковал выездные трансляции в районах, организовал радиопередачи из студий районных радиоузлов. Несмотря на трудное время, руководитель уделял внимания коллективу радио, стимулируя ударный труд лучших работников эфира (НА РС (Я). Ф. 898. Оп. 2. Д. 9. Л. 11, 11 об. Личные дела).

С начала октября 1941 года по инициативе Республиканского комитета бойцов Красной Армии началась акция по сбору тёплых вещей для отправки на фронт, о проведении которой и участии жителей рассказывали в новостях. В знаменательную дату - в день Октябрьской революции 1941 года - передавали доклад И.В. Сталина, выступившего на торжественном собрании Московского городского Совета, этот же доклад в переводе на якутский язык был передан на следующий день. Военная обстановка в г. Якутске обязала радиокомитет оборудовать репродукторы на центральных улицах, в трудовых коллективах и учебных заведениях, возле которых собиралась масса людей для группового слушания сообщений Совинформбюро и других новостей. Призыв на военную службу продолжался. Всего в 1941 г. было призвано 16964 человека, из них пять тысяч были отправлены на фронт и получили первое боевое крещение. В основном были комсомольцы, которые воевали в передовых гвардейских рядах на фрронте, о них часто рассказывали у микрофона организаторы комсомольской работы, политинформаторы. Выступали у микрофона руководители Совнаркома Якутской АССР, секретари обкома партии и комсомола. Передавали лекции в помощь агитаторам и пропагандистам по истории партии, по актуальным вопросам Отечественной войны. Дикторы часто читали подготовленные политической редакцией статьи: "Окружение нашими войсками 16-й немецкой армии", "Фронтовые заметки", "Идея патриотизма", "Полгода войны советского народа против гитлеровской Германии", "О грабежах, разорениях жителей и чудовищных зверствах германских властей на советских территориях", "Как гитлеровская Германия грабила оккупированные территории" и др. (НА РС (Я). Ф. 898. ОП. 4. Д. 26. Л. 7-14. Программа радиопередач 1942 г.).

Значимое место в радиопублицистике занимали митинги и собрания, имевшие массовый политический резонанс на территории республики. Примером стал состоявшийся 6 сентября 1942 года в Драматическом театре антифашистский митинг против разжигателей войны, который транслировался по Якутскому радио. В конце митинга участники приняли обращение к советским воинам: "... От устья Лены до Москвы - далеко, но она в сердце у каждого якута, также дороги для нас и солнечный Кавказ, и город Ленина, степи Дона и Украина, поля Белоруссии и побережье Балтики. В ряды Красной Армии мы послали лучших сыновей. Каждому бойцу-якуту на фрронте мы даем суровый наказ: "Сын якутского народа, ты - советский воин! В твоих руках судьба нашей Отчизны. Будь достойным своего народа! Будь отважен и смел, как те богатыри, дравшиеся с черными силами, о которых отцы и деды пели в своих олонхо!"'" [2, с. 5].

Первая официальная делегация из Якутии выехала на Западный фрронт в действующую армию с посылками для бойцов. По приезду делегации в Якутск состоялся митинг, который транслировали по республиканскому радио 19 марта 1942 г. дежурные редакторы политвещания К.И. Платонова и М.И. Цимахович, редактор выпуска радиопрограмм А.В. Гуляева, ведущие дикторы В. Абрамова и М. Белолюбский (НА РС (Я). Ф. 898. Оп. 2. Д. 9. Л. 35. Фонд личного состава отдела кадров 1942 г.). Моральная и материальная поддержка бойцов Красной Армии продолжалась. Республиканский комитет инициировал вторую акцию по сбору тёплых вещей для отправки на фрронт, где принимали участие жители г. Якутска, 32-х районов республики и промышленного Алданского округа (НА РС (Я). Ф. 4. Оп. 16. Д. 293. Л. 210. Информации по организации подарков для бойцов Красной Армии в 1942 г.). Кроме того к 25-й годовщине Октябрьской револющии собрали средства на строительство танковой колонны "Советская Якутия" и во второй раз 
отправили посылки на фрронт на "воинском эшелоне". Делегация вылетела в начале октября из г. Якутска через г. Иркутск на Западный фрронт. В составе делегации был главный редактор Якутского радиокомитета В.М. Новиков.

Творческая группа редакторов и переводчиков политического вещания регулярно готовила выход в эфир оперативных передач и докладов руководителей республики. Это ответственное задание добросовестно выполняли главный редактор сектора политического вещания М.М. Захаров, редактор К.Е. Захаров, старшие дикторы Н.П. Черкашина и П.С. Омуков. Кроме того циклы передач "В помощь семьям фронтовиков", "Письма из фронта", "Слушай нас, молодёжь Якутии!" нашли место в әфире радио в рабочие дни. Постоянно освещался вопрос сельского хозяйства. В годы войны из-за засушливой погоды саранча уничтожала посев зерновых культур и сенокосные угодья. Из-за этого экстренно решался вопрос переселения колхозов в рыболовецкие артели. При этом радиокомитет возглавил политическую кампанию и организовал специальные выпуски радиопередач о работе рыболовов северных районов. В радиопередачах использовались письма колхозников об экономическом состоянии и выполнении планов по заготовке рыб для фрронта.

В оперативной подготовке политических радиопередач о начале учебного года, ходе социалистического соревнования, подготовке колхозников к уборке урожая и зимовке скота по-новому зазвучали радиопереклички, радиомитинги, выступления у микрофона. В качестве красных уголков организовали в северных районах "Агитационные оленьи нарты" по добыче пушнины среди кочевых народов. Выступали у микрофона не только руководители Наркомов, но и механизаторы, работники коллективных хозяйств (НА PC (Я). Ф. 898. Оп. 4. Д. 23. Л. 47-48. Программа радиопередач 1941 г.).

Духовные ценности национального праздника Ыһыах сохранились и в трудные годы войны. Впервые в период войны в июне 1944 года организовали празднование летнего солнцестояния и подготовку к сенокосу в сельскохозяйственных районах республики. Ыһыах вызвал патриотический настрой и небывалый подъём производительности труда у сельских работников, а редакторы политического вещания передавали по радио трудовые успехи и достижения победителей весеннего посева зерновых культур и механизаторов машинно-тракторных станций, ударников животноводческих фрерм и коневодства, юных помощников ученических бригад.

Приближение победы и конец войны поднимали творческий настрой коллектива Якутского радиокомитета. Утром 9 мая 1945 года, услышав сводку Совинформбюро, коллектив радио вышел на улицу. "Во дворе провели митинг. Руководство разрешило разойтись по домам, но никто не уходил. Вскоре собрали радиотехников, дали задание срочно оборудовать площадь Ленина для прямой трансляции. Бригада в составе монтёров, техников и инженеров срочно погрузила две подводы с радиоаппаратурой. Этот день остался в памяти самым незабываемым днём в жизни" [5, с. 55]. В г. Якутске состоялся митинг Победы, транслировалась праздничная программа по местному радио "Здравствуй, наша Победа!". В дни всенародного ликования республика готовилась к национальному празднику "Ыһыах Победы" (НА РС (Я)). Ф. 898. Оп. 4. Д. 45. Л. 20. Микрофонные материалы).

Таким образом, в Якутском радиокомитете функционировала ежедневно длинноволновая радиостанция РВ-62 на вещании и дублировала ее коротковолновая радиостанция РАХ в 1941-1945 гг. С военной обстановкой была введена новая сетка передач, изменилось соотношение видов вещания, где политическая редакция занимала лидирующее положение среди литературно-драматической, детской, музыкальной редакций. Кроме официальных сообщений Совинформбюро и "Последних известий" редакторами политического вещания готовились цикловые передачи на якутском и русском языках и внестудийные эфиры для трансляции торжественных заседаний, посвященных знаменательным датам 20-летия Якутской АСCР, Октябрьской революции, 15-летия общественно-политической оборонной организации Осоавиахима. Практиковались спецвыпуски по призыву граждан в ряды Рабоче-Крестьянской Красной Армии. В заключение следует отметить, что политическое вещание Якутского радио как средство мобилизации народной силы на помощь фронту и на трудовой подъём в тылу имело огромное значение в 
политико-пропагандистской работе на обширной территории Якутской АССР в годы Великой Отечественной войны.

\section{Литература}

1. Алексеев В.К. Моя забота о радиокомитете // Петрова В.Д. Якутское радиовещание. Якутск: Сахаполиграфиздат, 2000. 224 с.

2. Антифашистский митинг якутского народа: выступления представителей якутского народа. Якутск: Типография, 1942. 44 с.

3. Дальний Восток СССР: 1941-1945 гг. / История Дальнего Востока России. Т. 3. Кн. 3. Под общ. ред. чл. корр. РАН Н.Н. Крадина, отв. ред. Г.А. Ткачева. Владивосток: Дальнаука, 2020.994 с.

4. Зяблицева С.В. Радиовещание в индормащионном пространстве Западной Сибири периода Великой Отечественной войны // Вестник Челябинского государственного университета. 2011. № 22 (237). История. Выпуск 46. С. 66-70.

5. Климовский Н.Н. Замечательный коллектив радио // Петрова В.Д. Якутское радиовещание. Якутск: Сахаполиграфиздат, 2000. 224 с.

6. Костякова Ю.Б. Радиовещание Хакасии в условиях военного времени (19411945 гг.) // Вестник Военного университета. 2011. № 2 (26). С. 136-141.

7. Крюкова Г.М. Молодёжные радиопередачи в годы Великой Отечественной войны (на примере Башкирской АCСР) // Genesis: исторические исследования. 2019. № 9. C. 1-7.

8. Никитина С.Е. Региональные органы управления общественно-политической жизнью Якутской АССР в годы Великой Отечественной войны // Северо-Восточный гуманитарный вестник. 2019. № 1 (26). С. 46-58.

9. Петрова Р.И. Вспомним сердцем своим: монография / Р.И. Петрова, В.С. Сивцева, С.И. Петрова, М.Н. Максимова. Якутск: Издательский дом СВФУ, 2015. 408 с.

10. Сомов В. А. Радио как коммуникативное средство формирования трудовой мотивации в годы Великой Отечественной войны 1941-1945 гг. (на примере Волго-Вятского региона) // Новейшая история России. 2012. №1. С. 132-144.

11. Хисамутдинова Н.В. Радио слушали все: Приморское радио в годы Великой Отечественной войны. Территория новых возможностей // Вестник Владивостокского государственного университета экономики и сервиса. 2018. Т. 10. № 2. С. 186-194.

12. Шагдарова Б.Б. Радиовещание Бурятии в годы Великой Отечественной войны // Новый исторический вестник. 2010. № 4 (26). С. 103-108.

\section{Транслитерация по ГОСТ 7.79-2000 Система Б}

1. Alekseev V.K. Moya zabota o radiokomitete // Petrova V.D. YAkutskoe radioveshhanie. YAkutsk: Sakhapoligrafizdat, 2000. 224 s.

2. Antifashistskij miting yakutskogo naroda: vystupleniya predstavitelej yakutskogo naroda. YAkutsk: Tipografiya, 1942. $44 \mathrm{~s}$.

3. Dal'nij Vostok SSSR: 1941-1945 gg. / Istoriya Dal'nego Vostoka Rossii. T. 3. Kn. 3. Pod obshh. red. chl. korr. RAN N.N. Kradina, otv. red. G.A. Tkacheva. Vladivostok: Dal'nauka, 2020. 994 s.

4. Zyablitseva S.V. Radioveshhanie v informatsionnom prostranstve Zapadnoj Sibiri perioda Velikoj Otechestvennoj vojny // Vestnik CHelyabinskogo gosudarstvennogo universiteta. 2011. № 22 (237). Istoriya. Vypusk 46. S. 66-70.

5. Klimovskij N.N. Zamechatel'nyj kollektiv radio // Petrova V.D. YAkutskoe radioveshhanie. YAkutsk: Sakhapoligrafizdat, 2000. 224 s.

6. Kostyakova YU.B. Radioveshhanie KHakasii v usloviyakh voennogo vremeni (1941-1945 gg.) // Vestnik Voennogo universiteta. 2011. № 2 (26). S. 136-141.

7. Kryukova G.M. Molodyozhnye radioperedachi v gody Velikoj Otechestvennoj vojny (na primere Bashkirskoj ASSR) // Genesis: istoricheskie issledovaniya. 2019. № 9. S. $1-7$.

8. Nikitina S.E. Regional'nye organy upravleniya obshhestvenno-politicheskoj zhizn'yu YAkutskoj ASSR v gody Velikoj Otechestvennoj vojny // Severo-Vostochnyj gumanitarnyj vestnik. 2019. № 1 (26). S. 46-58.

9. Petrova R.I. Vspomnim serdtsem svoim: monografiya / R.I. Petrova, V.S. Sivtseva, S.I. Petrova, M.N. Maksimova. YAkutsk: Izdatel'skij dom SVFU, 2015. 408 s.

10. Somov V. A. Radio kak kommunikativnoe sredstvo formirovaniya trudovoj motivatsii v gody Velikoj Otechestvennoj vojny 1941-1945 gg. (na primere Volgo-Vyatskogo regiona) // Novejshaya istoriya Rossii. 2012. № 1. S. 132-144.

11. KHisamutdinova N.V. Radio slushali vse: Primorskoe radio v gody Velikoj Otechestvennoj vojny. Territoriya novykh vozmozhnostej // Vestnik Vladivostokskogo gosudarstvennogo universiteta ehkonomiki i servisa. 2018. T. 10. № 2. S. 186-194. 
12. SHagdarova B.B. Radioveshhanie Buryatii v gody Velikoj Otechestvennoj vojny // Novyj istoricheskij vestnik. 2010. № 4 (26). S. 103-108.

Петрова В. Д. Якутское радио в годы Великой Отечественной войны: редакция политического вещания.

В статье рассматривается деятельность редакции политического вещания Якутского регионального радиокомитета в годы Великой Отечественной войны на основе вводимых в научный оборот новых документальных материалов, которые еще не стали предметом исследования в отечественной историографии. С началом войны главное место на радио занимало политическое вещание, которое направляло основную нагрузку радиопередач на мобилизацию народной силы в оказании помощи фронту и на стимулирование трудового подвига в тылу. В статье изложено тематическое содержание политического вещания, включая сводку Совинформбюро, материалов ТАСС, выпусков "Последних известий" и трансляции главных новостей из Москвы. Проводится анализ организации информационно-пропагандистских радиопередач, настроения жителей и участия творческого актива общественных организаций в подготовке радиоматериалов, на основе которого подводится итог идейно-политической, массово-стимулирующей роли радиовещания в 1941-1945 гг. в Якутии.

Ключевые слова: Якутское радио, политическое вещание, Великая Отечественная война, Советское информационное бюро, радиослушатель

\section{broadcastinga}

The article examines the activities of the editorial office of political broadcasting of the Yakut regional radio Committee during the great Patriotic war on the basis of new documentary materials introduced into scientific circulation, which have not yet become the subject of research in Russian historiography. With the beginning of the war, the main place on the radio was occupied by political broadcasting, which directed the main load of radio broadcasts to mobilize people's power in helping the front and stimulating labor feats in the rear. The article describes the thematic content of political broadcasting, including a summary of the Sovinformburo, TASS materials, issues of "Latest news" and broadcasts of the main news from Moscow. Analyzes the organization of awareness-raising broadcasts, the mood of the people and participation of the creative asset of public organizations in the preparation of radio materials on the basis of which sums up the ideological-political, mass-stimulating the role of the radio in 1941-1945.

Key words: Yakutsk radio, political broadcasting, World War II, Soviet information bureau, radio listener

Для цитирования: Петрова В. Д. Якутское радио в годы Великой Отечественной войны: редакция политического вещания // Ойкумена. Регионоведческие исследования. 2020. № 4. C. 65-70. DOI: 10.24866/1998-6785/2020-4/65-70

For citation: Petrova V. D. Yakut radio during the great Patriotic war: political broadcasting // Ojkumena. Regional researches. 2020. № 4. P. 65-70. DOI: $10.24866 / 1998-6785 / 2020-4 / 65-$ 70 